\title{
Difficulties of fishing at Lake Naivasha, Kenya: is community participation in management the solution?
}

\author{
Rodrick Kundu, ${ }^{1}$ Christopher Mulanda Aura, ${ }^{2 *}$ Mucai Muchiri, ${ }^{3}$ James Murithi Njiru ${ }^{3}$ \\ and Jacob E. Ojuok ${ }^{4}$
}

${ }^{1}$ Ministry of Fisheries Development, Fisheries Department, Kisumu, Kenya, ${ }^{2}$ Kenya Marine and Fisheries Research Institute, Mombasa, Kenya, ${ }^{3}$ Department of Fisheries and Aquatic Sciences, School of Natural Resource Management, Moi University, Eldoret, Kenya, and ${ }^{4}$ Kenya Marine and Fisheries Research Institute, Baringo, Kenya

\begin{abstract}
Unlike other lakes in tropical regions, Lake Naivasha exhibits low fish species diversity. The fishery is based on introduced fish species that are not native to the lake. The lake ecosystem is very fragile, as reflected in its fluctuating fish catches. The fishery almost completely collapsed in 2001, due partly to mismanagement and ignorance about needed conservation measures. The Kenyan government, like many governments around the world, recognized the need to involve fishers and other stakeholders, in order to ensure better management of the lake fisheries resources. Also referred to as collaborative management (co-management), this management approach provides the opportunity to share responsibility for managing the fishery resources between the government and the community. A total ban on fishing was imposed in February 2001, lasting for 1 year, to allow lake fish stocks to recover. This study analyses the co-management process for Lake Naivasha, and discusses the role played by the community during the fishing ban, as well as the successes and challenges encountered, and the tribulations and perceptions of the fishers regarding the new management strategy. It also comprises the first documentation of community participation in fisheries management begun for Lake Naivasha in the year 2001.
\end{abstract}

\section{Key words}

co-management, fisher folk, fishery, fishing ban, Lake Naivasha.

\section{INTRODUCTION}

Co-management of resources involves the sharing of roles and management responsibilities between the government, the resource users and other interested stakeholders (Pomeroy 2004). This type of strategy was initiated in 2001 for Lake Naivasha. This lake $\left(0^{\circ} 45^{\prime} \mathrm{S}\right.$, $36^{\circ} 20^{\prime} \mathrm{E}$; altitude $1890 \mathrm{~m}$ above sea level) is a small, shallow freshwater lake in the eastern Rift Valley, $\approx 100 \mathrm{~km}$ northwest of Nairobi, Kenya, and covering a surface area of $\approx 160 \mathrm{~km}^{2}$ (Hickley et al. 2002). It supports a number of economic activities, including fishing. Other activities include horticulture, tourism and water for domestic use and geothermal generation. As a result of its rich, unique biodiversity, coupled with threats from anthropogenic activities, Lake Naivasha was declared a wetland of inter-

\footnotetext{
*Corresponding author. Email: caura@kmfri.co.ke or auramulanda@yahoo.com

Accepted for publication 10 October 2009.
}

national importance in 1994 under the Ramsar Convention (LNRA, 1999). The lake contains six introduced species of fish and an introduced crustacean specie, including Micropterus salmoides Lacépède (largemouth bass), Oreochromis Leucostictus (Trewewas) (tilapia), Tilapia zillii (Gervais), Cyprinus carpio (common carp), Barbus amphigramma Blgr., Leticulus reticulate Peters (guppy) and Procambrus clarkii (crayfish). The only endemic fish species Aplocheilichthys antinorii (Vinc.) was last recorded in 1962 (Elder et al. 1971). The history of fish introductions was discussed by Litterick et al. (1979) and Muchiri and Hickley (1991). Commercial fishing was begun in 1959, being based on the largemouth bass and the two tilapia species (Muchiri \& Hickley 1991) and, more recently in 2002, the common carp. The lake fishing industry currently employs more than 1000 Kenyans, as well as providing a source of protein for area residents and others in nearby towns. Several factors threaten the Lake Naivasha fishery. A primary threat is 
uncontrolled and excessive fishing, which seriously affects recruitment rates. Also problematic is the rampant use of prohibited fishing gears, and disturbances of the fish breeding grounds in the shallow lakeshore areas. Enforcement of fisheries regulations is also weak.

As in many other parts of the world, the Lake Naivasha fishery has been treated as 'open access' property, to be exploited by each and every individual (both legally and illegally) according to their needs, and their capacity to harvest the fish (Hardin 1968). Related fishery threats include unpredictable lake-level fluctuations (Becht \& Harper 2002), encroachment on riparian land and potential pollution from the surrounding farmlands (Harper et al. 1990), armed and violent illegal fishers, dishonest government officials and lack of awareness about sustainable exploitation of the lake fishery. All factors contributed to the near collapse of the fishery. Against this background, this study highlights the use of co-management arrangements for Lake Naivasha for its biological sustainability and continued economic viability of the fisheries resource for present and future generations.

\section{MATERIAL AND METHODS}

Two methods were used in this study. Historical background and secondary information was obtained from records of the Fisheries Department (FD), the Lake Naivasha Riparian Association (LNRA; a local communitybased organization), and Kenya Marine and Fisheries Research Institute (KMFRI) research reports on the Lake Naivasha Research Project. The second method employed was to review existing publications on co-management and Lake Naivasha. The experiences and involvement of the lead author from the inception of the process in 2001-2004, when he was the Fisheries Officerin-Charge of the area, was also utilized.

\section{Co-management process for Lake Naivasha}

This study reviewed and utilized the conceptual framework on necessary structures for co-management (Ikwaput 2005), decentralization of co-management (Pomeroy \& Viswanathan 2003), management improvement and deterioration (Thomson \& Gray 2008), and the role of the government in this process (Pomeroy 2004). The FD conducted consultative meetings with Lake Naivasha stakeholders towards the end of the year 2000, including fishermen and land owners (Pomeroy 2004), with the goal of addressing the problem of declining fish stocks after years of excessive fishing. It was decided that, as the government has been unable to manage the fishery, there was a need to change the management approach to include the primary fishery stakeholders. This approach defined a paradigm shift in management from the old top-down approach to a participatory and collaborative approach, namely co-management. Thus, based on consultative meetings between the government and stakeholders, a fish recovery strategy was implemented. Based on consensus, it was unanimously agreed that the lake should be closed to fishing for a specified period of time to allow the lake fish stocks to recover. This goal was achieved via a legal gazette notice that enforced a total fishing ban, going into effect on 10 February 2001.

\section{Enforcement of the fishing ban}

A task force management committee was formed immediately when the fishing ban was imposed, being mandated to complete the modalities and develop guidelines for proper management of the Lake Naivasha fishery (Pomeroy \& Viswanathan 2003; Pomeroy 2004). The task force composition comprised the FD, KMFRI, Kenya Wildlife Service, LNRA (representing land owners), Beach Management Committees (representing fishers) and Lake Naivasha Fishermen's Cooperative Society. The membership of the task force was later expanded, however, to include the provincial administration, Kenya police authorities, Ministry of Water, Fish Traders Association and Naivasha Municipal Council. The task force expansion facilitated formation of the Fish Protection Unit (FPU), chaired by the local district officer. The highlights of the guidelines to be implemented by FPU included: (i) active involvement and participation of the local community in fisheries management (policing, research and licensing); (ii) creation of awareness among resource users, and those in authority, to promote responsible fishing practices; (iii) identification of alternative and complementary sources of economic livelihoods; (iv) development of modalities for reducing the number of fishers when the lake is opened to fishing; (v) identification of fish breeding zones involving fisher folk; and (vi) sourcing funds to supplement government funding. To enhance policing of the lake as a means of enforcing the ban, a community-sponsored vigilante group, comprising fishers and reformed fish poaches, was formed to assist the FPU.

During the first year (2001), public education campaigns were conducted to increase the general public understanding of sustainable use of the lakes' fishery (Ikwaput 2005). These campaigns involved public assembly meetings (barazas) that included government to fishers/community, government to government officials and fisher/community to fisher/community linkages. Through the LNRA, community members contributed 
funds, and provided material support, to supplement the cost of establishing the new management strategy (Table 1).

The funds were used for training workshops for fishers, traders, police and judiciary officials; lake patrols and research activities; repairing fisheries boats and purchasing outboard engines and mobile phones; consultative meetings; and honoraria for the vigilante group. This was also the period during which co-management regulations were also developed by the FPU. The main actors in the co-management process and their primary interests are identified in Table 2 and Fig. 1, with the roles of the various stakeholders also highlighted in Table 3.

One year after the fishing ban went into effect, fishermen were interviewed by the FPU. Guidelines were developed and agreed upon by all stakeholders for
Table 1. Financial contribution from Lake Naivasha stakeholders, 2001

\begin{tabular}{|c|c|c|}
\hline Stakeholder & Cash (KES) & Other support \\
\hline Anonymous & 100000 & \\
\hline Lake Crops (Mr Burch) & 5000 & Land transport, petrol, surveillance \\
\hline Sher Agencies & 200000 & Land transport, redeployment of fishers \\
\hline Orpower 4, Inc. & 60000 & \\
\hline Homegrown & 50000 & Land transport, redeployment of fishers \\
\hline Dr and Ms Irvine & 3000 & \\
\hline Dr Leon Bennun & 1500 & \\
\hline Mr John Barton & 10000 & Surveillance \\
\hline Sanctuary Farm & 10000 & \\
\hline Brig Wilson Boinett & 10000 & \\
\hline Longonot Farm & 40000 & Land transport, redeployment of fishers \\
\hline Mr. Jeremy Block & 400000 & Air surveillance \\
\hline Kijabe Ltd (Ms S Higgins) & & $\begin{array}{l}\text { Land transport, air surveillance, petrol, } \\
\text { redeployment of fishers }\end{array}$ \\
\hline Crescent Island (Mr Gaymer) & 86100 & Land, water and air surveillance, petrol \\
\hline Oserian Dev Company & & $\begin{array}{l}\text { Land and water transport, surveillance, } \\
\text { redeployment of fishers }\end{array}$ \\
\hline Mr Michel Lejeune & & Water transport, petrol, surveillance \\
\hline Mr Waithaka Mbuthia & & Water transport \\
\hline Wildfire Ltd (Mr Szapary) & & $\begin{array}{l}\text { Land transport, petrol, surveillance, } \\
\text { redeployment of fishers }\end{array}$ \\
\hline Shalimar Flowers & & Redeployment of fishers, surveillance \\
\hline Ms Joan Root & 1343400 & Land transport, petrol, surveillance \\
\hline Horticulture Farm & & Land transport, petrol, surveillance \\
\hline Mr Peter Low & & Land transport, petrol, surveillance \\
\hline Mbegu Farm & & $\begin{array}{l}\text { Land transport, surveillance, } \\
\text { redeployment of fishers }\end{array}$ \\
\hline Lake Naivasha Country Club & & Water transport \\
\hline Elsamere Conservation Centre & & Water transport, petrol \\
\hline Fisherman's Camp, Crayfish & & Surveillance \\
\hline \multicolumn{3}{|l|}{ Camp and Fish Eagle Inn } \\
\hline Mr Robertson & 35000 & \\
\hline LNRA & 100000 & $\begin{array}{l}\text { School fees for fishers kids, liaison } \\
\text { office, financial sourcing }\end{array}$ \\
\hline Hort Tech (Mr Schuppach) & & Land transport, petrol \\
\hline Yatch club (Mr Moses Kinyua) & & Water transport, surveillance \\
\hline John Dolier & & Land transport \\
\hline Lake Naivasha Growers Group & 300000 & \\
\hline
\end{tabular}

Source: LNRA and Fisheries Department. 
Table 2. Stakeholders and their interests regarding Lake Naivasha

\begin{tabular}{ll}
\hline Stakeholder & \multicolumn{1}{c}{ Interest } \\
\hline Fisheries department/government, KWS & $\begin{array}{c}\text { Revenue, management } \\
\text { conservation } \\
\text { Conservation }\end{array}$ \\
LNRA & Cess from fish, \\
Naivasha Municipal Council & sewage disposal \\
& Cess from fish \\
Lake Naivasha Fishermen Cooperative & \\
Society & Research \\
KMFRI & Livelihood \\
Fishers/traders &
\end{tabular}

KMFRI, Kenya Marine and Fisheries Research Institute; KWS, Kenya Wildlife Service; LNRA, Lake Naivasha Riparian Association.

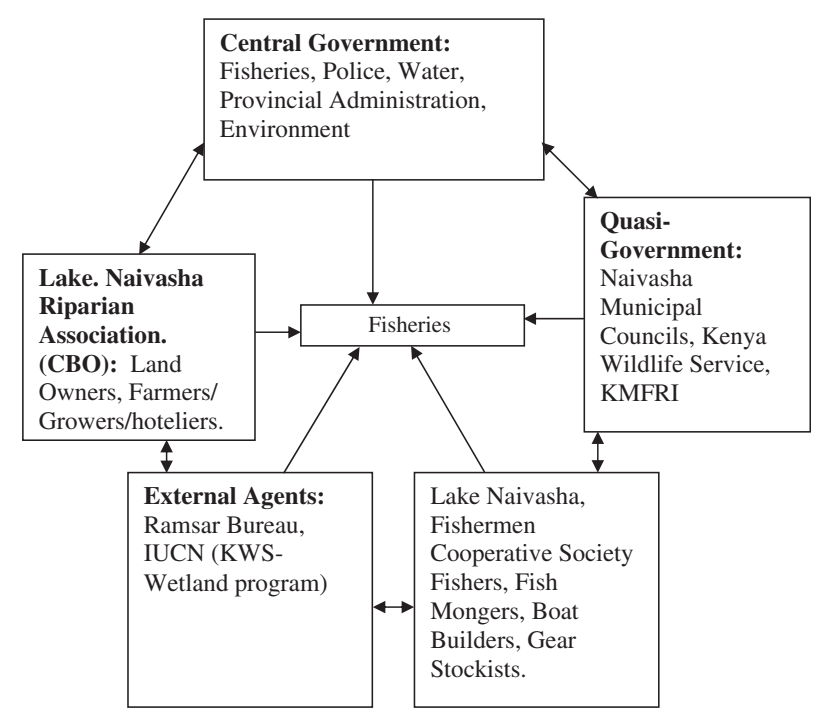

Fig. 1. Stakeholders involved in co-management of Lake Naivasha fisheries resources.

Table 3. Responsibilities of various Lake Naivasha groupings

\begin{tabular}{lccc}
\hline Task & FD & FPU & BMC \\
\hline Rule formulation & & $\times$ & $\times$ \\
Enforcement & $X$ & $X$ & $\times$ \\
Control of access & & & $\times$ \\
Licensing & & $X$ & $\times$ \\
Research & & $X$ & $\times$ \\
Financial sourcing & & $X$ & \\
Sanctions and appeals & & $X$ & \\
\hline
\end{tabular}

Source: Fisheries Department.

BMC, Beach Management Committees; FD, Fisheries Department; FPU, Fish Protection Unit.
Table 4. Lake Naivasha Scoreboard

\begin{tabular}{lr}
\hline Criteria & Score \\
\hline Boat owner/bonafide fisher/real fishers & 5 \\
Applicants with no other livelihoods & 4 \\
Applicants has no criminal records & 3 \\
Applicant is a member of BMC & 2 \\
Applicant shortlisted by BMC & 1 \\
Applicant attended interview & 1 \\
Total score & 16 \\
\hline
\end{tabular}

Source: Fisheries Department.

BMC, Beach Management Committees.

screening fishermen, and reducing fishing effort, based on research efforts. Relevant guidelines included issuing fishermen's licenses only to the people with no other source of economic livelihood. This was to ensure consistency with the government's strategy for poverty alleviation, with priority given to fishers who personally go on the fishing trips. The goal was to eliminate absentee/telephone fishers. Only one fishing boat per family was licensed. In cases where more than one family member applied, preference was given to those supportive of the current fishery management process. A few reformed illegal/uninformed fishers were also considered. Based on these screening criteria, the FPU selected 43 boat owners out of the $>200$ applications (Table 4). As a result of the screening, the 43 interviewees who scored the highest marks were licensed to carry out fishing on a research protocol after the ban was lifted, all to use gill nets and canoes.

\section{RESULTS}

As a result of the Lake Naivasha co-management process, several measures were agreed upon through consensus, and put into effect to enhance management of the lake fishery after the fishing ban was lifted. They included: (i) annual stakeholder consultative meetings for sharing information and research progress reports; (ii) an annual closed fishing season during June to September, as per legal notice number 214 of 2003; (iii) collaborative research and monitoring involving relevant stakeholders to be carried out on a continuous basis; and (iv) a fishing effort limit of $40-50$ boats to be licensed each year, as recommended by researchers. Each boat should have three crews, and a maximum of 10 gill nets of recommended mesh size, a daily limit of five fish per fishing rod for sport fishers; introduction of daily fish movement passes for fish traders to account for the fish purchased at landing beaches to the markets. These measures were 
monitored by law enforcers that involved the Beach Management Units (BMUs), in order to ensure compliance of the fisheries regulations at the beach, the surveillance of areas in their jurisdiction and to create awareness and resolve conflicts at the fishers' level, as well as the FPU role of overseeing surveillance, licensing and sanctions against illegal fishers.

As a result of such measures, there has been a general improvement in fish catches since the implementation of this co-management approach. The high fish catches experienced before the ban was composed primarily of juvenile fish caught with undersized nets (Fig. 2). A comparison of the monthly fish catch per boat indicates that, a single boat landed $44 \mathrm{~kg}$ of fish on average during the entire month in January 2001 with an uncontrolled number of fishing gears. In comparison, for the same month, 4 years later (2005), a boat landed on average $310 \mathrm{~kg}$ of fish in a month, with a maximum of 10 fishing gill nets (Table 5).

It has been observed that legal fishermen are now using large mesh-sized nets, as recommended by law. This is a good sign of compliance with agreed actions, as the fishers were deeply involved in the development of the co-management regulations. Their compliance demonstrates a sense of ownership of rules in which they were participants in developing. The participation of the community in the management process has enhanced trust and cooperation between fishers, government officials and land owners. This has been substantiated by the larger financial contributions from land owners for management of the lake (Table 1), and which has improved the lake and market surveillance (Table 6). The security of the patrol teams also improved from the previous situation of violent confrontations between government officers and illegal fishers, which is attributed to the creation of awareness among community members. BMUs and Welfare groups have been formed, and have

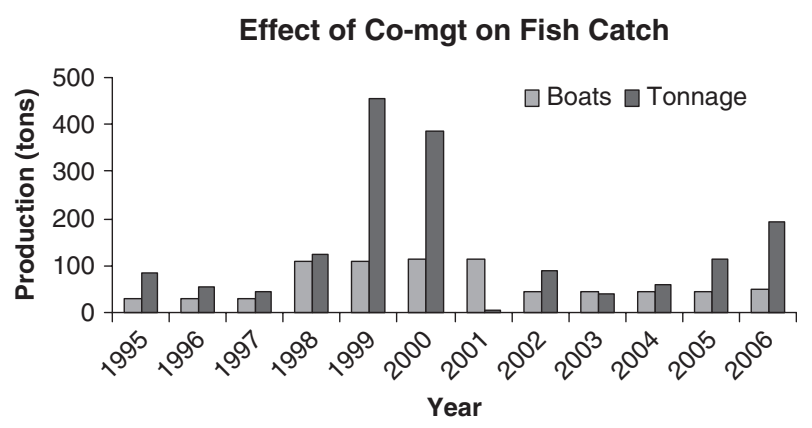

Fig. 2. Fish production and number of boats (Source: Fisheries Department).
Table 5. Fish catch comparison for January 2001 and 2005

\begin{tabular}{lrr}
\hline Year & \multicolumn{1}{c}{2001} & \multicolumn{1}{c}{2005} \\
\hline Fish production $(\mathrm{kg})$ & 5000 & 13942 \\
Value (KShs) & 213000 & 585788 \\
Number of boats & 113 & 45 \\
\hline
\end{tabular}

Source: Fisheries Department.

Table 6. Monitoring, control and surveillance

\begin{tabular}{lccc}
\hline Year & $\begin{array}{c}\text { Suspects } \\
\text { arrested }\end{array}$ & $\begin{array}{c}\text { Illegal nets } \\
\text { impounded }\end{array}$ & $\begin{array}{c}\text { Illegal boats } \\
\text { impounded }\end{array}$ \\
\hline 2000 & 46 & 62 & 7 \\
2001 & 112 & 793 & 25 \\
2002 & 238 & 3000 & 26 \\
2003 & 94 & 1198 & 15 \\
2004 & 136 & 310 & 13 \\
2005 & 38 & 738 & 10 \\
2006 & 82 & 261 & 13 \\
2007 & 16 & 480 & 2 \\
\hline
\end{tabular}

Source: Fisheries Department.

been supportive in solving beach-related conflicts, especially at the fisher to fisher level. They have also opened bank accounts to open financial savings channels and provide credit facilities among fishers and traders at the beach level.

Community policing had its pitfalls; however, in that there was resentment from uninformed fishers who believed illegal to be arrested by fellow fishers. In retaliation, illegal fishers engaged in stealing boats and fishing gears belonging to licensed fishermen. The result was reluctance on the part of some licensed fishers to fully participate in lake fish patrols. In addition, some fishers leaked information about the patrols to their unlicensed friends engaging in illegal fisheries activities.

\section{DISCUSSION}

The essence of establishing a co-management system for Lake Naivasha constitutes a framework to promote community involvement in the management of its fishery (Pomeroy \& Viswanathan 2003; Thomson \& Gray 2008). The wealth of experience and indigenous knowledge is an asset in the decision-making process, instilling a sense of stewardship in the lake and its resources. The initial enthusiasm among lakes stakeholders in being part of the new management style laid the foundation for generous contributions to supplement implementation of 
the co-management process. This positive experience is not indicative of most donor-supported fisheries co-management engagements in Africa, which are typically managed under conditions tailored to meet donor expectations, with the community being relegated to being recipients of donor instructions (Hara \& RaakjærNielsen 2002).

For more than 40 years after its independence, the administration of fisheries resources in Kenya was based on a top-down approach controlled by the central government. This top-down management style had no provision for involving fisheries stakeholders in the fishery decision-making process (Lwenya \& Abila 2003). Chapter 378 of the Fisheries Act (revised in 1991) is applied on a command-and-control basis, being considered by fishers for a long time to be a repressive tool. Its implementation for Lake Naivasha is weak partly because of such factors as insufficient funding to the fisheries station, a shortage of personnel related to the governments' civil service reform programme and a freeze on employment. These factors undermine mounting effective surveillance activities.

The reality is that the Fisheries Act is too lenient, therefore not being a significant deterrent to illegal fishing as most offenders get light sentences and fines, or committed to do community service. It is also worth noting that the changing economic times, coupled with poor civil service salaries, compromised the role of the fisheries staff as law enforcers. In fact, some officers collude with unscrupulous fisher folk to supplement their earnings, seriously damaging the fishery resource in the process. This unfortunate situation is not uncommon for most lakes in eastern Africa (Owino 1999). Another factor promoting unethical behaviour is having staff working in the same office for long periods (i.e. more than 20 years), and whose only source of motivation is leaking surveillance plans in return for bribes. This is why it was imperative to overhaul the staff establishment at the onset of the fishing ban, as a means of providing an opportunity for new officers from other fisheries stations around the country.

The interaction between government officials and stakeholders under the old management scheme helped fishers develop perceptions about the lake fishery and the new fishery management style. Some had the impression that fisheries management was a government affair and, therefore, expected little change under the new management approach. In fact, despite being participants in the initial development of the co-management strategy, the fishing community was unhappy when the fishing ban was put into effect, claiming marginalization from their only livelihood source. The fishers accused the horticultural farms around the lake of being responsible for the lake's declining water level because of their water abstraction, and their water pumps sucking fish fry out of the irrigation canals. They further accused the horticulture farms of retrenching thousands of young men who depend on the lake to steal fishing equipment and poach for their survival (Yongo 2002). Against this attitude, compliance with the fishing ban period remained poor, with some fishers joining illegal poachers to violate the legal notice. Even after the lake was opened for trial fishing, there was a lack of conformity by some licensed boats regarding mesh-size requirements and recommended fishing effort limits. Paradoxically, most fishers redeployed in the horticultural industry returned to the lake for their livelihood, whether licensed or not. This suggests the need for time necessary to change old habits established over decades through the previous topdown management approach. Poor compliance with Lake Naivasha fish regulations by fishers is consistent with the experience with Lake Kariba when co-management was introduced in the 1990s (Nyikahadzoi \& Songore 1999).

Although the ban on fishing had positive biological consequences, its effects on the lifestyles of fisher folk were harsh. Yongo (2002) noted that most of the fishers did not accumulate monetary savings, and those who were not successfully employed within the horticulture industry because of poor health or old age ended up doing odd jobs (e.g. breaking stones in quarries). Family break-ups and evictions by landlords were not uncommon. It is clear that the fishing ban was a very trying period in the fisher folk community.

The violence that followed the disputed December 2007 General Elections caused further misery for a section of the fisher community. Authentic experienced fishers were chased away from fishing activities, with their places being taken over by increased numbers of unruly poachers resistant to law and order. As a result of the postelection violence, the only gazetted fish landing site was closed down (Kinyua V, pers. comm.). This scenario poses a big challenge to fishery co-management, and to the fragile fishery in general. It is imperative, therefore, that adequate sensitization and training are available to change the perception of newcomer fishers.

Ikwaput (2005) noted the significance of having necessary structures on the ground to enhance the co-management structure. Some structures are already in place at Lake Naivasha to boost the new co-management strategy. A Lake Naivasha management plan, developed to address sustainable management issues of the lake environment through consensus-building, is in place (Enniskillen, 2002). Although its legality has been challenged in courts 
of law, the plan is gazetted through a legal notice by the government under the Environmental Management and Coordination Act, 1999. It is being implemented by a government-appointed Management Committee, with representation from fisher folk. Through this committee, fisher's views are heard at the highest unifying organ dealing with sustainable management of the lake and its wider catchment.

A subsidiary legislation to legalize the formation of country-wide BMUs by the government was effected in 2007. This legislation will address delegated authority frameworks, creating an enabling legal environment to support co-management efforts by fishers at the beach level (Pomery \& Berkes 1997), holding BMU committee members accountable for their responsibilities. These beach leadership reforms are likely to create some social friction, however, by disrupting the traditionally established leadership and power base among the fisher folk at the beach level (Sen \& Raakjær-Nielson 1996). The formation of BMUs is based on the democratic principle whereby the various stakeholders at the beach have an equal chance to compete for leadership positions. People who previously never had a voice in the leadership arrangement (e.g. fishing crews, boat and net repairers, fish mongers) have now assumed powers through the democratic process. This situation is certain to create discomfort among the people who were previously unchallenged in controlling affairs at the beach level. Hara and Jul-Larsen (2003) observed that power-brokers in traditional beach leadership at Lake Malombe in Malawi were mostly influential people, including boat owners, fishing gear owners, and powerful middlemen or fish traders.

Sometimes, such disgruntled former officials will tend to undermine the present management establishment, especially when the beach leader or chairman is regarded, by beach standards, to be of a lower social status. Also being a function of the same democratic process, local power and authority might fall into the hands of leaders, or groups that lack training and leadership capabilities, and might reverse the gains of the new process because of a lack of commitment to the values and goals of co-management. Under such circumstances, capacity building and provision of technical support to fishers is paramount for smooth operations of BMUs.

The issue of equity on the part of fishers at Lake Naivasha is partly addressed by the amendment of the Fisheries Act to establish BMUs, as the fisher's participation in co-management is now legitimized. The fisher folk's proposal to open up two more ungazzetted fish landing sites at Kamere (south lake) and Tarambeta (north lake) was considered, and can be interpreted as acceptance of their views in the decision-making process. The BMU legislation, however, does not favour the local residents around the lake, some of whom were appointed as fisheries co-managers by the Director of Fisheries, and are waiting to be made honorary fish wardens once the relevant legislature is in place. They cannot currently arrest law breakers, or give prosecution evidence in court of law, as they are not empowered to do so. This category of stakeholders was very instrumental in providing the logistics to jumpstart and establish the co-management process. There is a possibility that a delay in granting them legal backing would be perceived as disinterest on the part of government in ceding power and management responsibilities to sections of the community.

A co-management strategy for Lake Naivasha, however, faces a combination of problems. The current population growth around Lake Naivasha, for example, poses a big threat to the fishery. Many unemployed youth who cannot find employment opportunities in the flower farms tend to change to fishing for economic reasons. The large numbers of employees in the horticulture industry also provide an incentive for illegal fishing as there is a ready market for poached fish. This problem is further complicated by the current reforms of decongestion in the Prisons Department that allows many convicts, including fisheries offenders, to serve non-custodial sentences that allow them to continue fishing to earn a living.

In addition, some of the local political establishment were not happy with the new management regime for the lake. They felt that the new method was implemented to exclude some people from accessing the lake for their livelihoods. Accordingly, cases of incitement for people to promote illegal fishing activities were not uncommon. This is an issue that was regularly addressed during annual stakeholders meetings, however, although co-management does not address the politics of inclusion or exclusion of citizens in sustainable exploitation of natural resources. There is also a need for continuous sensitization and management updates of the local political leadership.

Another threat is that long-term financial support from land owners and residents might not be feasible because of the lack of sufficient incentives for cooperation, and empowerment for genuine participation in co-management efforts. Thus, unless proper structures are implemented to source funding to supplement government support, this situation might affect the co-management implementation process.

Nevertheless, in spite of the above threats, based on the co-management initiative introduced and conducted around Lake Naivasha, it was noted that community 
participation in making rules for the fishery increased the effectiveness of implementation and the sense of ownership of the same rules. Collaborative work with lake patrols, together with constant interactions, creates trust and transparency among fishers and extension officers. Using organized beach leadership, the fisher folk are able to solve their own conflicts. Furthermore, community education creates a sense of appreciation towards responsible fishing, and the community has the potential to organize itself if appropriately empowered. Illegal fishermen also appreciate the reasoning behind the new approach, unlike the situation prior to implementation of co-management efforts, when rule enforcement was surrounded with hostility. There was minimal confrontation after the first 2 years, although old habits die hard, with fishermen continuing to try circumventing the agreed rules of responsible fishing. Furthermore, those fishermen redeployed to other sectors (e.g. horticulture industry) eventually return to fishing, whether legally or illegally. Co-management at Lake Naivasha occurred as a result of problem recognition in resource management related to resource deterioration. It offered the opportunity for increased participation and empowerment of the fisher community. Co-management is viewed as an evolving learning process that adjusts and matures over time. Thus, in order to strength the co-management strategy, there is need to revisit the Lake Naivasha experience, in order to re-evaluate the level of understanding and acceptance of co-management process among stakeholders. Furthermore, legal structures (e.g. fisheries policy) should be developed and implemented to create positions of honorary fish wardens, and to secure sustainable funding from stakeholders. Fisheries personnel also should not be deployed at the Lake Naivasha station for more than 3 years unless otherwise necessary. Finally, the government should provide an improved staff, or consider providing incentives for officers working at the station, as they work beyond official hours.

\section{ACKNOWLEDGEMENTS}

Thanks are given to the Fisheries Department, Naivasha, KMFRI and the Lake Naivasha Riparian Association for providing some of the information used in the preparation of this report.

\section{REFERENCES}

Becht R. \& Harper D. M. (2002) Towards an understanding of human impact upon the hydrology of Lake Naivasha. Hydrobiologia 488, 1-11.

Elder H. Y., Garrod D. T. \& Whitehead P. J. P. (1971) Natural hybrids of the African cichlid fishes Tilapia spirulus nigra and T. leucosticta, a case of hybrid introgression. Biol. J. Linn. Soc. 3, 103-46.

Enniskillen D. (2002) Introduction: the Lake Naivasha Management Plan - consensus-building to conserve an international gem. Hydrobiologia 488, 168: 9-12.

Hara M. \& Raakjær-Nielsen J. (2002) A Decade of Fisheries Co-management in Africa: Going Back to the Roots? Empowering Fishing Communities? Or Just an Illusion? Occasional Paper Series No. 20, Programme for Land and Agrarian Studies, University of Western Cape, South Africa.

Hardin G. (1968) The tragedy of the commons. Science 162, 1243-8.

Harper D. M., Mavuti K. M. \& Muchiri S. M. (1990) Ecology and management of Lake Naivasha, Kenya in relation to changing climate, alien species introductions and agricultural development. Eviron. Conserv. 17, 328-36.

Hickley P., Bailey R., Harper D. M. et al. (2002) The status and future of the Lake Naivasha fishery, Kenya. Hydrobiologia 488, 181-90.

Ikwaput J. N. (2005) Community participation in fisheries management: prospects and challenges for co-management. In: Knowledge and Experiences Gained from Managing Lake Victoria Ecosystem, pp. 595-612. Colour Print (T) Ltd, Dar es Salaam, Tanzania. ISBN 99878976-5-7.

Litterick M. R., Gaudet J. J., Kalff J. \& Melack J. M. (1979). The limnology of an African lake, Lake Naivasha, Kenya. Workshop on African Limnology, SIL UNEP, Nairobi: 61 pp.

LNRA. (1999) Lake Naivasha Management Plan. Lake Naivasha Riparian Association, Naivasha, Kenya, 77 pp.

Lwenya C. \& Abila R. O. (2003) Co-management in the Lake Victoria fishery, realities, constrains and opportunities in Kenya. In: Lake Victoria Fisheries: Status, Biodiversity and Management (eds M. van der Knaap \& M. Munawar). Aquatic Ecosystem Health and Society. Available from URL: www.aehms.org. Accessed 13 December 2009.

Muchiri S. M. \& Hickley P. (1991) The fishery of Lake Naivasha, Kenya. In: Catch Effort Sampling Strategies: Their Application in Freshwater Fisheries Management (ed. I. G. Cowx), pp. 382-92. Fishing News Books, Blackwell Scientific Publications, Oxford.

Nyikahadzoi K. \& Songore N. (1999) Introducing co-management arrangement in Lake Kariba inshore fishery: progress, opportunities and constraints. Proceedings of the International Workshop on Fisheries Co-management; 23-28 August 1999, Penang, Malaysia. 
Owino J. O. (1999) Traditional and central management systems of the Lake Victoria fisheries in Kenya. Socioeconomics of the Lake Victoria fisheries. Report No. 4, IUCN Eastern Africa Programme, Nairobi, Kenya, 24 pp.

Pomeroy R. S. (2004) Devolution and Fisheries Co-management. ICLARM, Manila, $62 \mathrm{pp}$.

Pomeroy R. S. \& Viswanathan K. K. (2003). Experiences with Fisheries Co-management in Southeast Asia and Bangladesh. Kluwer, Dordrecht, pp. 101.

Pomery R. S. \& Berkes F. (1997) Two to tango: the role of government in fisheries co-management. Marine Policy, 21, 465-80.
Sen S. \& Raakjær-Nielson J. (1996) Fisheries co-management. A comparative analysis. Marine Policy, 20, 40516.

Thomson K. \& Gray T. (2008) From community-based to co-management: improvement or deterioration in fisheries governance in the Cherai Poyil Fishery in the Cochil Estuary, Kerala, India? Marine Policy, 33, 537-43.

Yongo E. O. (2002) Lake Naivasha: the dilemma of resource use and conservation. Current Status of Fisheries, Water Quality and Socio-economics of Lake Naivasha. Final Report December 2002, Kenya Marine \& Fisheries Research Institute, Naivasha, Kenya. 